\title{
Exploring the role of self-control on student procrastination
}

\author{
Hariz Enggar Wijaya ${ }^{{ }^{*}}$, Arief Rahman Tori ${ }^{1}$ \\ ${ }^{1}$ Islamic University of Indonesia, Yogyakarta, Indonesia \\ *Corresponding author, e-mail: hariz.wijaya@uii.ac.id
}

\begin{abstract}
Procrastination is widespread across the nation and setting. Its occur commonly in an academic setting which has many demands and deadline. One of the variable construct which reported has a high association with procrastination is self-control. It is why we would like to find out the role of self-control on student procrastination. There were 100 undergraduate students enrolled this study, from religious education faculty of a private university in Yogyakarta. Pure Procrastination Scale, Procrastination Academic Scale for Student, and Brief Self-Control Scale were administered to obtain student procrastination and self-control. Results showed that self-control correlates moderately negative with both of general and academic procrastination. Also, self-control could predict procrastination both in an academic and general setting. As an additional, there were significantly different between the lowest and highest procrastination group based on student self-control, with big size-effect reported. For further analysis, the prevalence of six areas of academic procrastination also discuss.
\end{abstract}

Keywords: Procrastination, Self-control, Undergraduate students.

How to Cite: Wijaya, H. E., \& Tori, A. R. (2018). Exploring the role of self-control on student procrastination. International Journal of Research in Counseling and Education, 2(1), 12-18. https://doi.org/10.24036/003za0002

\section{Introduction}

There is no doubt that controlling our behavior is so crucialto achieving a positive outcome. Both in personal, organizational, or community context, daily or professional context, people need to be wellmanaged to achieve one's success.As an example, we cannot imagine if an employee who failed to get up early in the morning, could get good compensation from the company. Also, in the academic example, a student who could not override the short-term temptation such playing game, would have trouble in accomplishing an academic task.

Having a good self-control is beneficial to our life. Denson, DeWall, \& Finkel, (2012)review of self-control experiments, has underlined the important role of self-control to override the aggressive urges. Lackingsuch self-control would predict aggressive behavior and high self-control tends to reduce aggressive response. Another study amplifies the substantial role of self-control, which identifies both implicit and explicit selfcontrol had an influence on aggressive tendency (Keatley, Allom, \& Mullan, 2017).

At the macro level of several counties in Texas, Diamond, Jennings, and Piquero (2017) study have shown that self-control was associated with violent crime, property crime, and unemployment, especially in rural areas. The key feature of self-control such impulsive and unhealthy behavior, linked with unemployment. Converse, Beverage, Vaghef, and Moore, (2018) confirm the influence of self-control on work. It could predict not only work but also relationship issue and well-being in adolescent and young adult. The association between self-control and health also reported by Yang, Zhao, Chen, Zu, and Zhao (2017), wheredepressed university students reported has benefited from self-control training.

In an academic setting, self-control gives pivotal role in determining success. Candeias et al., (2014) has shown that self-control positively associatewith academic self-efficacy and school satisfaction in primary and secondary school. It also affirms by Galla and Duckworth longitudinal study (2015), student self-control gives valuable affect to homework habits, homework accomplishment, higher school grade, and also GPA and college persistence. It gives corroboration that self-control not merely about inhibit temptation. 
Alongside with that issue, self-discipline reported has become reliable predictor than IQ in predicting student grade, school attendance, homework time spent, and high school selection(Duckworth \& Seligman, 2005). Supporting this finding, Komarraju, Ramsey, and Rinella (2013), found that academic discipline better in predicting college GPA than standardized test scores (ACT) and high school GPA. It partially mediated the correlation between high school GPA and college GPA.

Another indicator of academic success is the way student deal with the academic demand and deadline. Whether they would accomplish or postpone the tasks, become matters. A student who tend to procrastinate, tend to have a problem. As Gustavson and Miyake (2017) investigated, a college student who reported as high procrastinate tend to have low on goal accomplishment. According toSteel (2007), selfcontrol highly associated with procrastination. It means that student who has a problem with their selfcontrol tends to procrastinate on an academic task. Kim, Hong, Lee, and Hyun (2017)study also point out thatstudents who have high self-control reported have low on procrastination. Delaying or postpone behavior,indicate poor on self-control. In this present study, we would like to explore the role of self-control on student procrastination.,both in an academic context and general procrastination.

Method

Participants

There were 100 undergraduate students ( 47 males and 53 females) enrolled this study. They were from the faculty of Islamic religion in private university Yogyakarta, which has an age from nineteen to twenty-two years old.

\section{Instruments}

Data were obtained with three self-report. There were Brief Self-Control Scale, Pure Procrastinate Scale, and Procrastination Academic Scale for Student. The Brief Self-Control Scale was self-report scale to assess unidimensional trait self-control, which developed by Tangney, Baumeister, and Boone (2004). It has 13 items which Cronbach's $\square$ in this sample is 0.78 and item-total correlation ranged from $0.58-0.63$. This scale used a Likert model with five alternative responses, ranging from strongly disagree, disagree, hesitation, agree, and strongly agree.

Academic procrastination was assessed by using Procrastination Academic Scale for Student, developed by Solomon and Rothblum (1984). These 12 itemsself-report coversof six academic domains: Writing a term paper, studying for exams, keeping up with the weekly reading task, academic administration task, attendance task such meeting with advisor and college activity in general. Likert responses also used in this scale, ranging from never, seldom, about half the time, usually, andalways. Cronbach's $\square$ in this sample reported 0.89 and item-total correlation were $0.49-0.73$.

General procrastination was measured by using Pure Procrastination Scale(Steel, 2010). This self-report derived from three meta-analyses of General Procrastination Scale, Adult Inventory of Procrastination, and Decisional Procrastination Questionnaire (DPQ), which composed of 12 items. According to recent refinement scale, Svetina, Marie Scott, Danckert, Svartdal, and Steel, (2017)stated that the PPS has good psychometric properties. It comprises of three subscales, namely decisional procrastination, implemental delay, and timeliness/lateness. In this sample, Cronbach's $\square$ was 0.92 and the item-total correlation was ranging from 0.39 - 0.76. Five Likert responses also applied: strongly disagree, somewhat disagree, neutral, somewhat agree, and strongly agree.

\section{Procedure}

All of the three questionnaires were given to the undergraduate student at the end of three classes. Permission from the Dean of religion faculty was taken before the questionnaires distributed. After researcher introduced, the material was given to the student by asking their cooperation. They were told that they have to fill up the questionnaires and there were no wrong or right answers.

\section{Data analysis}

Correlation analysis was employed to determine the relationship between self-control and both procrastination. Regression analysis wasapplied in order to find procrastination predictor. As an addition, independent t-test also applied to compare between the low and high group of procrastination based on selfcontrol. 


\section{Results and Discussion}

\section{Result}

The descriptive analysis has shown (Table 1)that there were 36\% students who identified themselves procrastinate on academic demands. Along with that, general procrastination of student also indicates at the same level, 39\%. More than a third of the sample reported having the problem with delayed behavior. Of them, $19 \%$ students having a high risk to meet the deadline.

Table 1. Descriptive Statistics of general and academic procrastination

\begin{tabular}{lcc}
\hline & PASS & PPS \\
\hline $\mathrm{N}$ & 100 & 100 \\
Mean & 33.89 & 34.90 \\
S.D & 8.058 & 9.143 \\
Very Low & $18 \%$ & $15 \%$ \\
Low & $22 \%$ & $25 \%$ \\
Moderate & $24 \%$ & $11 \%$ \\
High & $17 \%$ & $20 \%$ \\
Very high & $19 \%$ & $19 \%$ \\
\hline
\end{tabular}

From correlation analysis table 2 shown that self-control has negative and significant correlation on procrastination, both academic domain and general( $\mathrm{r}=-.32 \mathrm{p}<.01$ and $\mathrm{r}=-.45, \mathrm{p}<.001)$. The self-control explains $10 \%$ on theacademic procrastinationvariance andtwice higher in explaining $20 \%$ general procrastinationvariance (see table 3 ).

Table 2. Correlation between PASS, PPS, and Self-control

\begin{tabular}{llccc}
\hline & & PASS & PPS & Self-control \\
\hline PASS & Pearson's $\mathrm{r}$ & - & & \\
& p-value & - & & \\
PPS & Pearson's $\mathrm{r}$ & $0.548^{* * *}$ & - & \\
\multirow{4}{*}{ Self-control } & p-value & $<.001$ & - & \\
& Pearson's $\mathrm{r}$ & $-0.321^{* *}$ & $0.450^{* * *}$ & - \\
& p-value & 0.001 & $<.001$ & - \\
\hline & $\mathrm{p}<.05,{ }^{* *} \mathrm{p}<.01,{ }^{* * *} \mathrm{p}<.001$ & & & \\
\hline
\end{tabular}

Whether self-control could predict procrastination, regression analysis was applied. Self-control variable significantly predicted both academic and general procrastination $(\beta=-.32, \mathrm{~F}=11,23 ; \mathrm{df}=1 ; \mathrm{p}<0.01$ and $\beta=-.63, \mathrm{~F}=24,82 ; \mathrm{df}=1 ; \mathrm{p}<0.001$ ). Self-control explain $10,3 \%$ of the variance in academic procrastination. In the general context, self-control do higher explain $20,2 \%$ of the procrastination variance (see Table 3).

Table 3. Summary of Regression Analysis for Predicting procrastination $(\mathrm{N}=100)$

\begin{tabular}{lcccccc}
\hline & \multicolumn{3}{c}{ Model 1 (PASS) } & \multicolumn{3}{c}{ Model 1 (PPS) } \\
\hline & $B$ & $S E B$ & $\beta$ & $B$ & $S E B$ & $\beta$ \\
Self-control & -.395 & .118 & $-.321^{* *}$ & -.628 & .126 & $.450^{* * *}$ \\
$R^{2}$ & & .103 & & & .202 & \\
$F$ & & 11.23 & & & 24.82 & \\
\hline$*^{* *} p<01^{* * * *}>001$ & & & & &
\end{tabular}


Some study indicates that gender has an influence on procrastination(Steel \& Ferrari, 2012; Rebetez, Rochat, Barsics, \& Van Der Linden, 2016)and self-control(Candeias et al., 2017; Duckworth \& Seligman, 2006; Jo \& Bouffard, 2014). Data analysis revealed that of three variables, only self-control having a difference between male and female, which female $(M=44.49, S D=6.02)$ superior to male $(M=41.89, S D=6.89)$. There were no significant differences between male and female procrastination based on gender, both in academic and general context (see Table 4).

Table 4. Academic procrastination, general procrastination, and self-control differences based on gender

\begin{tabular}{lcccccc}
\hline & \multicolumn{2}{c}{ Male $(\mathrm{N}=47)$} & \multicolumn{2}{c}{ Female $(\mathrm{N}=53)$} & $\mathrm{df}$ & $\mathrm{t}$ \\
\hline & $\mathrm{M}$ & $\mathrm{SD}$ & $\mathrm{M}$ & $\mathrm{SD}$ & & \\
PASS & 33.96 & 7.99 & 33.83 & 8.19 & 98 & .078 \\
PPS & 35.68 & 9.54 & 34.21 & 8.81 & 98 & .803 \\
Self-control & 41.89 & 6.89 & 44.49 & 6.02 & 98 & $-2.01^{*}$ \\
\hline P & & & & & &
\end{tabular}

Independent sample t-test analysis was employed to compare low and high self-control group. Table 5 showed that there was significant procrastination difference between the two groups. The student having low self-control $(M=37.05, S D=8.11)$, procrastinate in academic setting higher than high self-control group ( $M=28.88, S D=9.05)$. At the same time, low self-control student $(M=40.86, S D=9.01)$, having general procrastination higher than high self-control group ( $M=29.46, S D=9.11)$.

Also, all of six academic procrastination domains were difference significantly between the two groups, except attendance task learning.Low self-control student reported having high procrastination on writing a paper, studying for exams, weekly reading assignment, academic administration task, and college activity in general and vice versa. As an addition, three areas of academic task which percept as most problematic, from highest to lowest were writing a paper, weekly reading assignment, studying for exams,

Table 5. Academic procrastination, general procrastination, and six domain of academic procrastination differences between low and high self-control group

\begin{tabular}{|c|c|c|c|c|c|c|c|c|}
\hline & \multicolumn{2}{|c|}{$\begin{array}{l}\text { Low self-control } \\
\qquad(\mathrm{N}=22)\end{array}$} & \multicolumn{2}{|c|}{$\begin{array}{l}\text { High self-control } \\
\qquad(\mathrm{N}=24)\end{array}$} & \multirow[t]{2}{*}{$\mathrm{df}$} & \multirow[t]{2}{*}{$\mathrm{t}$} & \multirow[t]{2}{*}{$\begin{array}{c}\text { Cohen's } \\
\text { d }\end{array}$} & \multirow{2}{*}{$\begin{array}{c}\text { Highly } \\
\text { perceived } \\
\text { as a } \\
\text { problem }\end{array}$} \\
\hline & $\mathrm{M}$ & SD & $\mathrm{M}$ & SD & & & & \\
\hline PASS & 37.05 & 8.11 & 28.88 & 9.05 & 44 & $398^{* *}$ & 0.51 & - \\
\hline PPS & 40.86 & 9.01 & 29.46 & 9.11 & 44 & $4.26^{* * *}$ & 1.26 & - \\
\hline Writing a paper & 3.455 & $\begin{array}{l}0.858 \\
0.907\end{array}$ & $\begin{array}{l}2.708 \\
2.458\end{array}$ & 0.859 & 44 & $382.5^{* *}$ & 0.45 & $40 \%$ \\
\hline $\begin{array}{l}\text { Studying for } \\
\text { exam }\end{array}$ & 3.182 & & & 1.215 & 44 & $369.5^{*}$ & 0.40 & $28 \%$ \\
\hline $\begin{array}{l}\text { Weekly reading } \\
\text { task }\end{array}$ & 3.455 & 1.011 & 2.958 & 0.999 & 44 & $351.0^{*}$ & 0.33 & $32 \%$ \\
\hline $\begin{array}{l}\text { Academic } \\
\text { administration } \\
\text { task }\end{array}$ & 3.045 & 0.899 & 2.125 & 1.035 & 44 & $402.0^{* *}$ & 0.52 & $20 \%$ \\
\hline Attendance task & $\begin{array}{l}3.136 \\
2.773\end{array}$ & $\begin{array}{l}1.037 \\
0.922\end{array}$ & 2.500 & 1.319 & 44 & 343.5 & 0.30 & $22 \%$ \\
\hline $\begin{array}{l}\text { College activity } \\
\text { in general }\end{array}$ & & & 1.708 & 0.859 & 44 & $421.0^{* * *}$ & 0,60 & $11 \%$ \\
\hline
\end{tabular}




\section{Discussion}

Exploring the role of self-control on student procrastination is the aim of this study. The results haveindicated that self-control gives an important role to both academic and common procrastination. It has a negative correlation with procrastination and reasonably as a predictor of procrastination, in academic and general areas. This finding underlines the previous study which has linked between the self-control and procrastination(Rebetez, Rochat, Barsics, \& Van der Linden, 2016; Steel, 2007; Steel \& Klingsieck, 2016; Ursia, Siaputra, \& Sutanto, 2013).

According to Park and Sperling(2012), a student who procrastinate displayed a failure of self-regulation across of behavior, cognitive, and motivation. The reason why student postponed their task is not concerning the absence of planning and intention or isn't aware of the negative consequence, but more likely poor of energy and willpower. They already have the goal, but the problem is to get a start or accomplish what they have done due the limit time. According toGollwitzer, Gawrilow, and Oettingen (2010), there are four obstacles lying between one's goal and implementation. Firstly, to get a start. Procrastinate student tends to hold off what they have planned. Usually, there was pleasure thing such playing or hanging out with a friend which alter initial planning. A student having low self-control would fail to resist that temptation. Secondly, to stay on track. After the student makes initial action to implement what has stated before, the problem still remains, how to constantly act until the finish. Many academic tasks, such writing a paper, couldn't accomplish just in a few minutes. It needs to keep in touch until done. Low self-control student tends to fail to stay on the track. Any distraction would inhibit the goal. Thirdly, calling a halt. A complex task or invaluable assignment is challenging for some individual. But for a student having poor self-control, it would be easy to make an excuse to call a halt. If this so, then any assignment would be abandoned. The last is not overextending oneself. Some goals which take a high resource would make student depleted. Such longterm project which required high control, yield cognitive load which in turn make ego-depletion.

The association between self-control and general procrastination is higher than in academic context, though it still in the moderate level. When it put as a predictor, self-control does better in predicting general academic twice than in an academic setting. This difference seems likely to reflect the domain specification of procrastination just asKlingsiecksuggest (2013), where trait self-control better in predictingtrait procrastination in general.

The difference between low and high self-control group on general and academic procrastination give an impression that association between two variables are salient, especially with large effect size reported on general procrastination. From six domains of academic procrastination, three of them having moderate effect size: college activity in general, academic administration assignment, and writing a paper and the rest were small effect size.

Based on the student report, they confess having a problem with the three most academic demands. At the top rank was writing a paper, followed by weekly reading task and studying for exams. It is not surprisingthat writing a paper is the most perceivedtask to as a problem. As Kellogg(1994) argues, writing is a complex process which comprises of four cognitive tasks. There are gathering ideas, plan it, translate to text, and reviewing. It is not only collecting knowledge in our head, but also a concern of intellectuality, motivation, cognitive style, and anxiety.

Gender issue on the self-control and procrastination were found only in self-control variable and no difference was reported in both academic and general procrastination. Consistent with the previous study (Candeias et al., 2017; Angela Lee Duckworth \& Seligman, 2006; Jo \& Bouffard, 2014), male and female were differing in self-control, which female reported better than male. But this finding differs with Wang, Fan, Tao, and Gao (2017), which yield on male superior in Asian sample. This inconsistency perhaps linked with the cultural background lying on the sample.

\section{Conclusion}

Finding on this study emphasize the role of self-control on procrastination. It has a moderate association with both academic and general procrastination. Self-control is better in predicting general procrastination than in academic context. The differences between the high and low self-control group in almost all of the academic procrastination domainamplified the key contribution of self-control in an academic setting, especially a college student. As a consequence, promoting one's capability to take more control in his own life would benefit, both in present and future. An academic institution should pay attention to this noncognitive factor to cultivate positive outcome. 


\section{References}

Candeias, A. A., Grácio, M. L., Oriol, X., Miranda, R., Oyanedel, J. C., \& Torres, J. (2017). The Role of Self-control and Grit in Domains of School Success in Students of Primary and Secondary School. Frontiers in Psychology, 8(1716), 1-9. https://doi.org/10.3389/fpsyg.2017.01716

Converse, P. D., Beverage, M. S., Vaghef, K., \& Moore, L. S. (2018). Self-control over time: Implications for work, relationship, and well-being outcomes. https://doi.org/10.1016/j.jrp.2017.11.002

Denson, T. F., DeWall, C. N., \& Finkel, E. J. (2012). Self-control and aggression. Current Directions in Psychological Science, 21(1), 20-25. https://doi.org/10.1177/0963721411429451

Diamond, B., Jennings, W. G., \& Piquero, A. R. (2017). Scaling-up self-control: A macro-level investigation of self-control at the county level. https://doi.org/10.1016/j.jcrimjus.2017.08.003

Duckworth, A. L., \& Seligman, M. E. P. (2005). Self-Discipline Outdoes IQ in Predicting Academic Performance of Adolescents. Psychological Science, 16(12), 939-944. https://doi.org/10.1111/j.14679280.2005.01641.x

Duckworth, A. L., \& Seligman, M. E. P. (2006). Self-discipline gives girls the edge: Gender in self-discipline, grades, and achievement test scores. Journal of Educational Psychology, 98(1), 198-208. https://doi.org/10.1037/0022-0663.98.1.198

Galla, B. M., \& Duckworth, A. L. (2015). More than Resisting Temptation: Beneficial Habits Mediate the Relationship between Self-Control and Positive Life Outcomes. J Pers Soc Psychol, 109(3), 508-525. https://doi.org/10.1037/pspp0000026

Gustavson, D. E., \& Miyake, A. (2017). Academic procrastination and goal accomplishment: A combined experimental and individual differences investigation. Learning and Individual Differences, 54, 160172. https://doi.org/10.1016/j.lindif.2017.01.010

Jo, Y., \& Bouffard, L. (2014). Stability of self-control and gender. Journal of Criminal Justice, 42(4), 356-365. https://doi.org/10.1016/J.JCRIMJUS.2014.05.001

Keatley, D. A., Allom, V., \& Mullan, B. (2017). The effects of implicit and explicit self-control on self-reported aggression. Personality and Individual Differences, 154-158. https://doi.org/10.1016/j.paid.2016.11.046

Kellogg, R. T. (1994). The psychology of writing. Acta Psychologica (Vol. 96). New York, NY: Oxford University Press. https://doi.org/10.1016/S0001-6918(97)00011-5

Kim, J., Hong, H., Lee, J., \& Hyun, M.-H. (2017). Effects of time perspective and self-control on procrastination and Internet addiction. Journal of Behavioral Addictions, 6(2), 229-236. https://doi.org/10.1556/2006.6.2017.017

Klingsieck, K. B. (2013). Procrastination in Different Life-Domains: Is Procrastination Domain Specific? Current Psychology, 32, 175-185. https://doi.org/10.1007/s12144-013-9171-8

Komarraju, M., Ramsey, A., \& Rinella, V. (2013). Cognitive and non-cognitive predictors of college readiness and performance: Role of academic discipline. Learning and Individual Differences, 24, 103-109. https://doi.org/10.1016/j.lindif.2012.12.007

Park, S. W., \& Sperling, R. A. (2012). Academic Procrastinators and Their Self-Regulation *, 3(1), $12-23$. https://doi.org/10.4236/psych.2012.31003

Rebetez, M. M. L., Rochat, L., Barsics, C., \& Van Der Linden, M. (2016). Procrastination as a self-regulation failure: The role of inhibition, negative affect, and gender. Personality and Individual Differences, 101(2016), 435-439. https://doi.org/10.1016/j.paid.2016.06.049

Solomon, L. J., \& Rothblum, E. D. (1984). Academic procrastination: Frequency and cognitive-behavioral correlates. Journal of Counseling Psychology, 31(4), 503-509. 
Steel, P. (2007). The Nature of Procrastination: A Meta-Analytic and Theoretical Review of Quintessential SelfRegulatory Failure. Psychological Bulletin, 133(1), 65-94. https://doi.org/10.1037/0033-2909.133.1.65

Steel, P. (2010). Arousal, avoidant and decisional procrastinators: Do they exist? Personality and Individual Differences, 48(8), 926-934. https://doi.org/10.1016/j.paid.2010.02.025

Steel, P., \& Ferrari, J. (2012). Sex, Education, and Procrastination : An Epidemiological Study of Procrastinators , Characteristics from a Global Sample. European Journal of Personality, Eur. J. Pers, 58, 51-58. https://doi.org/10.1002/per.1851

Steel, P., \& Klingsieck, K. B. (2016). Academic Procrastination: Psychological Antecedents Revisited. Australian Psychologist, 51(1), 36-46. https://doi.org/10.1111/ap.12173

Svetina, D., Marie Scott, L., Danckert, J., Svartdal, F., \& Steel, P. (2017). Irrational Delay Revisited: Examining Five Procrastination Scales in a Global Sample. Front. Psychol, 8(1927), 1-10. https://doi.org/10.3389/fpsyg.2017.01927

Tangney, J. P., Baumeister, R. F., \& Boone, A. L. (2004). High Self-Control Predicts Good Adjustment, Less Pathology, Better Grades, and Interpersonal Success. Journal of Personality, 72(2), 271-324. https://doi.org/10.1111/j.0022-3506.2004.00263.x

Ursia, N. R., Siaputra, I. B., \& Sutanto, D. N. (2013). Prokrastinasi Akademik dan Self-Control pada Mahasiswa Skripsi Fakultas Psikologi Universitas Surabaya. Makara Seri Sosial Humaniora, 17(1), 1-18. https://doi.org/10.7454/mssh.v17i1.1798

Wang, L., Fan, C., Tao, T., \& Gao, W. (2017). Age and gender differences in self-control and its intergenerational transmission. Child: Care, Health, and Development, 43(2), 274-280. https://doi.org/10.1111/cch.12411

Yang, X., Zhao, J., Chen, Y., Zu, S., \& Zhao, J. (2017). Comprehensive self-control training benefits depressed college students: A six-month randomized controlled intervention trial. Journal of Affective Disorders, 226, 251-260. https://doi.org/10.1016/j.jad.2017.10.014 